Çukurova Üniversitesi Mühendislik Mimarlık Fakültesi Dergisi, 29(1), 27-37 ss., Haziran 2014

Çukurova University Journal of the Faculty of Engineering and Architecture, 29(1), pp. 27-37, June 2014

\title{
Yüksek Fırın Cürufu ve Bazaltik Pomza Katkılı Betonların Hidro Aşınma Özelliklerinin Araştırılması
}

\author{
Hanifi BİNİCI *1 ${ }^{1}$, Ela Bahşude GÖRÜR ${ }^{2}$, Ahmet H. SEVİNÇ ${ }^{1}$, Mustafa EKEN $^{1}$ \\ ${ }^{l}$ K.S. Ü., Mühendislik-Mimarlık Fakültesi,İnşaat Mühendisliği Bölümü, Kahramanmaraş \\ ${ }^{2}$ K.S.Ü., Inşaat Teknolojisi Bölümü, Kahramanmaraş
}

\section{Özet}

Bu çalışmada, öğütülmüs yüksek firın cürufu ve bazaltik pomza ayrı ayrı veya birlikte kullanılarak üretilen betonların hidrolik aşınmaya dayanıklılığı araştıılmıştır. İnce agreganın yerine değişik oranlarda yüksek firın cürufu veya bazaltik pomza kullanılarak numuneler üretilmiştir. Üç yıl deniz suyu etkisine maruz kalan örneklerin aşınmaları kütle kayıplarına göre belirlenmiştir. Yüksek firın cürufu ve bazaltik pomza katkılı numunelerin aşınmaya karşı olumlu etkiler yaptığı görülmüştür. Beton dayanıklılığının, katkı tipi ve miktarına bağlı olduğu ortaya konmuştur. Ayrıca yüzde 80 yüksek firın cürufu içeren betonların deniz suyuna karşı dayanıklılı̆ı kontrol numunesinden daha yüksek bulunmuştur.

Anahtar kelimeler: Hidro aşınma, Yüksek firın cürufu, Pomza

\section{The Hydro-Abrasion Properties of Concretes Made with Blast Furnace Slag and Basaltic Pumice}

\begin{abstract}
In this study, ground granulated blast furnace slag and basalt together or separately using pumice abrasion resistance power of the concrete produced was investigated. In different proportions of fine aggregate instead of blast furnace slag or basalt samples were produced using pumice. Three years are exposed to sea water corrosion mass loss of the samples was determined according to. Blast furnace slag and basalt pumice for specimens which had a positive effect against abrasion were found. Concrete durability, depend on the type and amount of additives has been shown. In addition, 80 percent of concrete containing blast furnace slag resistances to seawater were higher than the control sample.
\end{abstract}

Keywords: Hydraulic abrasion, Blast furnace slag, Pumice

\footnotetext{
* Yazışmaların yapılacağı yazar: Hanifi BİNİCI, Kahramanmaraş K.S. Ü. Mühendislik Mimarlık Fakültesi, İnşaat Mühendisliği Bölümü, Kahramanmaraş.
} 


\section{GíRiş}

Çağımızın yapı dünyasında geniş bir kullanım alanı bulunan beton, üretimden uygulamaya kadar her aşamada son derece dikkat ve titizlik gerektiren temel bir yap1 malzemesidir. Beton çağdaş toplumların temelini oluşturan malzemelerin içerisinde önemli bir yere sahiptir. Çevremize baktığımızda binalar, yollar, köprüler, barajlar, santraller, istinat duvarları, su depoları, limanlar, hava alanları gibi yapılar betondan yapılmaktadır. Beton diğer yapı malzemelerine göre; daha kolay şekil verilebilir olması, ekonomik olması, dayanıklı olması, üretiminde daha az enerji tüketilmesi, her yerde üretilebilir olması ve estetik özellikleriyle en çok kullanılan yapı malzemesidir. Uygun şekilde üretilemeyen betonlar dış etkilere karşı dayanıksız olmaktadır.Yapıların bozulmasına yol açan fiziksel, kimyasal, biyolojik ve mekanik kökenli etmenler bulunmaktadır. Mekanik yolla oluşan hasarlar arasında, darbe, aşınma, erozyon ve oyulma (kavitasyon) etkileri sayılabilir [1-3]. Beton yüzeyine sürtünme veya çarpma şeklinde gelen kuvvetler, beton yüzeylerin yıpranarak tahrip olmasına yol açmakta ve yüzeyin aşınmasına neden olmaktadır.Farklı bir aşınma şekli de hareket halinde bulunan suların meydana getirdiği aşınmadır. Bir tür erozyon olarak kabul edilebilecek böyle bir duruma beton su borularında tünellerde, barajlarda ve dolu savaklarda rastlanılır. Buralarda suların gayet hızlı bir şekilde hareket etmesi sonunda kavitasyon olayı da meydana gelerek beton devamlı olarak tekrarlanan çarpma etkilerine maruz kalır. Bu tür etkiler betonun hem önemli derecede korozyon yapmasına ve hem de büyük bir hızla aşınmasına neden olur [4]. Betonun aşınma direnci üzerine yapılan araştırmalarda [5-8] aşınma direncinin, uygulanan test metotlarına, yüzey bitirme yöntemlerine, aşınma kuvvetlerine maruz kalacak beton yüzeyinin yapısal özelliklerine, kür şartlarına, mineral katkı maddesi kullanımına ve mukavemet özelliklerine bağlı olduğu belirtilmekte, dayanımı yakından ilgilendirmesi sebebiyle, su/çimento oranı, agrega-hamur ara yüzeyi, agrega ve bağlayıı madde hamuru kalitesi gibi faktörlerin de, aşınma direnci üzerinde etkili olduğu belirtilmektedir [9]. Aşınmaya karşı dayanıklı bir beton elde edebilmek için bazı mineral katkıların betona karıştırılması gerekmektedir. $\mathrm{Bu}$ amaçla metal agregaların ve çelik tozunun kullanılması iyi sonuçlar vermektedir. Bunlardan başka özel firınlarda silis ile karbonun birleştirilmesinden meydana gelen harç ve betonların aşınma değerleri düşük bulunmuştur [4].

Önceki birçok çalışmada YFC ve pomzanının betonda aşınmayı etkisi ve beton durabilitesine olumlu katkısı araştırılmıştır [10-13].

$\mathrm{Bu}$ çalışma ile denizde yapılan betonarme yapılarda meydana gelen kavitasyon ve kimyasal aşınma problemleri için uygun özel harç karışımları araştırılmıştır. K.S.Ü MühendislikMimarlık Fakültesi, İnşaat Mühendisliği laboratuvarında Osmaniye granüle bazaltik pomzası (GBP) ve yüksek firın cürufunun (YFC) betona katkı maddesi olarak katılmasının betonun kavitasyonuna, kimyasal aşınma etkisi deneysel olarak araştırılmıştır.

\section{MATERYAL VE METOT}

\subsection{Materyal}

\subsubsection{Yüksek Fırın Cürufu}

Demir elde edebilmek için, demir cevherlerinin firınlarda yaklaşık $1600{ }^{\circ} \mathrm{C}$ sıcaklığa kadar 1sitılmaları, böylece oksijenden ve yabanc1 maddelerden arındırılması gerekmektedir. Yüksek sıcaklığın etkisiyle, kok kömürünün karbonuyla demir oksitteki oksijen birleşerek karbondioksit ve karbon monoksit gazları oluşturarak firını terk etmektedir. Geride eriyik durumda demir ve eriyik durumda olan yabancı maddeler topluluğu kalmaktadır. Demirin yoğunluğu yabanc1 maddelerin yoğunluğundan daha yüksek olduğu için eriyik durumdaki demir firının en alt bölümünde ve eriyik durumdaki diğer malzemeler ise demirin hemen üzerinde yer alır. Demir ve diğer malzeme topluluğu ayrı ayrı çıkışlardan dişarı çıkarılmaktadır. $\mathrm{Bu}$ malzeme topluluğu "yüksek firın cürufu" olarak adlandırılmaktadır. 


\subsubsection{Pomza}

Pomza boşluklu, süngerimsi, volkanik olaylar sonucu oluşmuş, fiziksel ve kimyasal etkenlere karşı dayanıklı, gözenekli, camsı, volkanik bir kayaçtır. Yüksek oranda ve birbiriyle bağlantılı olmayan gözenekler içeren, \% 50’ye yakın nem suyu bulunduran ve dolayısıyla nemi alındığında özgül ağırlığ $0.5 \mathrm{~g} / \mathrm{cm}^{3}$ 'e kadar düşebilen, toz haline getirildiğinde oldukça sert malzeme özelliği kazanan, 1sı ve ses yalıtkanlığına, uygun basınç dayanımı ve elastisite modülüne sahip malzemedir. Asit veya bazik bileşimli olabilir. Asidik pomza, yeryüzünde en yaygın olarak kullanılan türüdür.

\subsubsection{Agrega}

Agrega, beton yapımında çimento ve su karışımından oluşan bağlayıcı madde yardımı ile bir araya getirilen, organik olmayan, kum, çakıl, kırma taş gibi doğal kaynaklı veya yüksek fırın cürufu, genleştirilmiş perlit, genleştirilmiş kil gibi yapay kaynaklı olan taneli malzemelerdir [14].

\subsection{4. Çimento}

Çimentolar su ile reaksiyon sonucu hem havada hem de su altında katılaştıkları ve sertleştikleri için hidrolik bağlayıcılar olarak sınıflandırılırlar. Çimento ile harç ve beton gibi çimentolu ürünler insanoğlunun geçmişte en fazla kullandığı ve gelecekte en fazla kullanacağı yapı malzemesi olmakla beraber aynı zamanda en fazla küçümsenen ve özellikleri en az bilinen yapı malzemeleridir. Çimento ve betonun iyi tanınmaması can ve mal kaybına neden olabilecek yanlış uygulamalara yol açabilmektedir [15].

Kullanılan agregaların fiziksel özellikleri Çizelge 1'de, agregaların elek analiz sonuçları ise Çizelge 2'de, YFC, bazaltik pomza ve çimentonun kimyasal içerikleri Çizelge 4'de, Çimentonun fiziksel analizleri Çizelge 3'de verilmiştir. Kimyasal içerikler için deneyler; Çukurova Üniversitesi Mühendislik Mimarlık Fakültesi, Türkiye Çimento Müstahsilleri Birliği, İskenderun Demir Çelik Fabrikası ve İskenderun OYSA Çimento Fabrikasında ayrı ayrı yapılmıştır.
Bulunan sonuçlar birbirlerine çok yakın değerler vermiştir.

Çizelge 1. Agregaların fiziksel özellikleri

\begin{tabular}{|c|c|c|}
\hline Özellik & $\begin{array}{c}\text { Ínce } \\
\text { Agrega }\end{array}$ & $\begin{array}{c}\text { Kaba } \\
\text { Agrega }\end{array}$ \\
\hline Özgül Ă̆ırlık & 2,73 & 2,75 \\
\hline $\begin{array}{c}\text { İncelik } \\
\text { modülü }\end{array}$ & 2,70 & - \\
\hline $\begin{array}{c}\text { Su Emme } \\
\text { Kapasitesi } \\
(\%)\end{array}$ & 0,80 & 1,22 \\
\hline $\begin{array}{c}\text { Boşluk Oranı } \\
(\%)\end{array}$ & 35,20 & 40,32 \\
\hline
\end{tabular}

Çizelge 2. Agregaların elek analiz sonuçları

\begin{tabular}{|l|c|c|c|}
\hline \multicolumn{2}{|c|}{ InceAgrega } & \multicolumn{2}{c|}{ KabaAgrega } \\
\hline Elek no. & $\begin{array}{c}\text { Yüzde } \\
\text { Geçen }\end{array}$ & Elek no. & $\begin{array}{c}\text { Yüzde } \\
\text { Geçen }\end{array}$ \\
\hline $150 \mu \mathrm{m}$ & 7,3 & $4.75 \mathrm{~mm}$ & 5 \\
\hline $300 \mu \mathrm{m}$ & 36,7 & $10 \mathrm{~mm}$ & 33.4 \\
\hline $600 \mu \mathrm{m}$ & 64,3 & $20 \mathrm{~mm}$ & 96.3 \\
\hline $1,18 \mathrm{~mm}$ & 74,8 & $40 \mathrm{~mm}$ & 100 \\
\hline $2,36 \mathrm{~mm}$ & 89,5 & & \\
\hline $4,75 \mathrm{~mm}$ & 97,6 & & \\
\hline
\end{tabular}

Çizelge 3. Çimentonun fiziksel özellikleri

\begin{tabular}{|c|c|c|c|}
\hline \multirow{2}{*}{$\begin{array}{c}\text { Özgül } \\
\text { ağırlık } \\
\left(\mathbf{g r} / \mathrm{cm}^{3}\right)\end{array}$} & \multirow{2}{*}{$\begin{array}{c}\text { Özgül } \\
\text { yüzey } \\
\left(\mathrm{cm}^{2} / \mathrm{gr}\right)\end{array}$} & \multicolumn{2}{|c|}{ İncelik } \\
\hline & & $\begin{array}{c}200 \mu \text { elek } \\
\text { üzerinde } \\
\text { kalan }(\%)\end{array}$ & $\begin{array}{c}90 \mu \text { elek } \\
\text { üzerinde } \\
\text { kalan }(\%)\end{array}$ \\
\hline 3,19 & 2800 & 0,09 & 0,3 \\
\hline
\end{tabular}


Çizelge 4. Çimento, YFC ve GBP'nin kimyasal içerikleri

\begin{tabular}{|c|c|c|c|}
\hline $\begin{array}{c}\text { Bileşenler } \\
(\%)\end{array}$ & Çimento & YFC & GBP \\
\hline $\mathrm{SiO}_{2}$ & 20,1 & 39,7 & 43,9 \\
\hline $\mathrm{Al}_{2} \mathrm{O}_{3}$ & 5,2 & 12,8 & 14,1 \\
\hline $\mathrm{Fe}_{2} \mathrm{O}_{3}$ & 3,9 & 1,7 & 12,1 \\
\hline $\mathrm{CaO}$ & 64,1 & 32,9 & 9,3 \\
\hline $\mathrm{MgO}$ & 2,2 & 7,4 & 8,9 \\
\hline $\mathrm{Na}_{2} \mathrm{O}+\mathrm{K}_{2} \mathrm{O}$ & 1,4 & 0,8 & 0,3 \\
\hline $\mathrm{SO}_{3}$ & 1,2 & 1,4 & - \\
\hline LOI & 0,5 & - & 0,5 \\
\hline \multicolumn{4}{|l|}{$\begin{array}{c}\text { EN 197-1 } \\
(\%)\end{array}$} \\
\hline $8 \mathrm{CaO} / \mathrm{SiO}_{2}$ & $\mathrm{MgO}$ & $\begin{array}{c}\mathrm{CaO}+\mathrm{SiO}_{2}+ \\
\mathrm{MgO}\end{array}$ & $\begin{array}{c}\mathrm{CaO}+ \\
\mathrm{MgO}) / \\
\mathrm{SiO}_{2}\end{array}$ \\
\hline$\geq 2$ & $<5$ & $\geq 66,7$ & $\geq 1$ \\
\hline
\end{tabular}

\section{2. Metot}

\subsubsection{Beton Karışımların Hazırlanması}

TS 802'ye uygun olarak yapılan beton karışımda ince agreganın \% 40, 60 ve 80'i oranlarında YFC ve GBP'nin her birini, birlikte veya ayrı ayrı katarak ve sadece kırma taş agregası kullanılarak üretilen kontrol örneği dahil 10 çeşit örneğin karışım hesabı yapılmıştır.

Örneklerin isimleri, karışım oranları ve kullanılan malzemeler Tablo 5'de verilmiştir. Bulunan karışım ağırlıklarına göre agregalar ve çimento hassas bir şekilde tartılarak betoniyerde karılmıştır.

Örnekler için hazırlanan beton karışımları TS 3068'deki esaslar dikkate alınarak yapılmıştır. TS 3068'de öngördüğü şekilde hazırlanan beton harmanlarından alınan deney örneklerinin betonun tüm özelliklerini taşımasına dikkat edilmiştir.

\subsubsection{Beton Örneklerin Aşınması}

Betonlarda meydana gelen aşınmalar hem deniz hem de laboratuvar ortamında yapılan çalışmalarla bulunmuştur. Beton örneklerin deniz suyu ortamındaki ağırlık kaybı değerleri laboratuar ortamında yeni geliştirilen bir sistemle bulunmuştur. $\mathrm{Bu}$ sistem Şekil 1 ve Şekil 2'de gösterilmektedir. Benzer bir yöntem ASTM'de yer almaktadır. Örnek boyutları için bir standart getirilmemiştir. $\mathrm{Bu}$ yüzden bu çalışmada, örnek

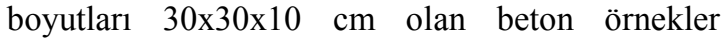
hazırlanmış ve laboratuardaki ortalama sıcaklığ $25^{\circ} \mathrm{C}$ olan deniz suyu ile dolu kür havuzunda bekletilmiştir. Deniz suyunun $\mathrm{pH}$ '1 her hafta ölçülerek, ph değeri 9,5'in üstüne çıktığında taze deniz suyu sağlanmıştır.

Kür havuzunda 5 gün deniz suyu ortamında sürekli devir daim çalışan aşağıdaki sistemde yüksek basınçlı deniz suyu ile fiziksel kavitasyon ve ağırlık kaybı bulunmuştur. Örneklerin bu sistemdeki aşınma değerleri kütle kaybı ölçülerek bulunmuştur.

\section{BULGULAR VE TARTIŞMA}

\subsection{Denizde Ortamında Bekletilen Beton Örneklerin Aşınma Değerleri}

Yüzey aşınması için üretilen $30 \times 30 \times 10 \mathrm{~cm}$ boyutlarındaki örnekler denizde doğal ortamda aşınmaya tabi tutulmuştur. Aşınmış örneklerin resimleri Şekil 3'de verilmiştir. Resimlerden özellikle kontrol örneğindeki aşınma dikkat çekmektedir. Bulunan sonuçlar ve Şekil 4'de verilmiştir.

Deniz ortamında aşınmaya bırakılan kontrol örneği diğer katkılı betonlardan daha fazla aşınmış ve 36 ay sonra ilk kütlesinden yaklaşık olarak \% 9,53 oranında kütle kaybı gerçekleşmiştir. Denize bırakılan örneklerden en fazla kontrol örneği aşınma gösterirken, S3 örneği \% 2,6 oran ile en az aşınmayı göstermiştir. Bunun yanında katkılı betonlar içinde en fazla aşınmayı da S7 örneği göstermiştir. 
Çizelge 5. Örneklerin isimleri ve karışım oranları.

\begin{tabular}{|c|c|c|c|c|c|c|c|c|c|}
\hline \multirow{2}{*}{$\begin{array}{c}\text { Numune } \\
\text { Adı }\end{array}$} & \multicolumn{7}{|c|}{ Beton Bileşenleri $\left(\mathrm{kg} / \mathrm{m}^{3}\right)$} & \multicolumn{2}{|c|}{ Yaş Beton Özellikleri } \\
\hline & $\mathrm{Su}$ & Çimento & Çakıl & Kum & Pomza & Cüruf & Katk1 & $\begin{array}{l}\text { Yoğunluk } \\
\left(\mathrm{kg} / \mathrm{cm}^{2}\right)\end{array}$ & $\begin{array}{l}\text { Beton Is1s1 } \\
\left({ }^{\circ} \mathrm{C}\right)\end{array}$ \\
\hline $\mathrm{C}$ & 135 & 300 & 1200 & 665 & - & - & 50 & 2315 & 20 \\
\hline$\% 20$ Bazalt & & & & & & & & & \\
\hline $\begin{array}{c}\text { \% } 20 \text { Cüruf } \\
\text { (S1) }\end{array}$ & 135 & 300 & 1200 & 400 & 130 & 130 & 75 & 2300 & 19 \\
\hline $\begin{array}{c}\% 30 \text { Bazalt } \\
\% 30 \text { Cüruf } \\
\text { (S2) }\end{array}$ & 135 & 300 & 1200 & 270 & 200 & 200 & 100 & 2310 & 18 \\
\hline $\begin{array}{c}\% 40 \text { Bazalt } \\
\% 40 \text { Cüruf } \\
(\mathrm{S} 3)\end{array}$ & 135 & 300 & 1200 & 150 & 260 & 260 & 75 & 2320 & 29 \\
\hline $\begin{array}{c}\% 40 \text { Bazalt } \\
\text { (S4) }\end{array}$ & 135 & 300 & 1200 & 390 & 260 & - & 100 & 2300 & 19 \\
\hline $\begin{array}{c}\% 60 \text { Bazalt } \\
\text { (S5) }\end{array}$ & 135 & 300 & 1200 & 280 & 400 & - & 100 & 2310 & 20 \\
\hline $\begin{array}{c}\% 80 \text { Bazalt } \\
\text { (S6) }\end{array}$ & 135 & 300 & 1200 & 145 & 520 & - & 100 & 2315 & 24 \\
\hline $\begin{array}{c}\% 40 \text { Cüruf } \\
\text { (S7) }\end{array}$ & 135 & 300 & 1200 & 405 & - & 260 & 75 & 2305 & 20 \\
\hline $\begin{array}{c}\% 60 \text { Cüruf } \\
\text { (S8) }\end{array}$ & 135 & 300 & 1200 & 280 & - & 400 & 100 & 2315 & 19 \\
\hline $\begin{array}{l}\text { \% } 80 \text { Cüruf } \\
\text { (S9) }\end{array}$ & 135 & 300 & 1200 & 160 & - & 520 & 100 & 2320 & 20 \\
\hline
\end{tabular}




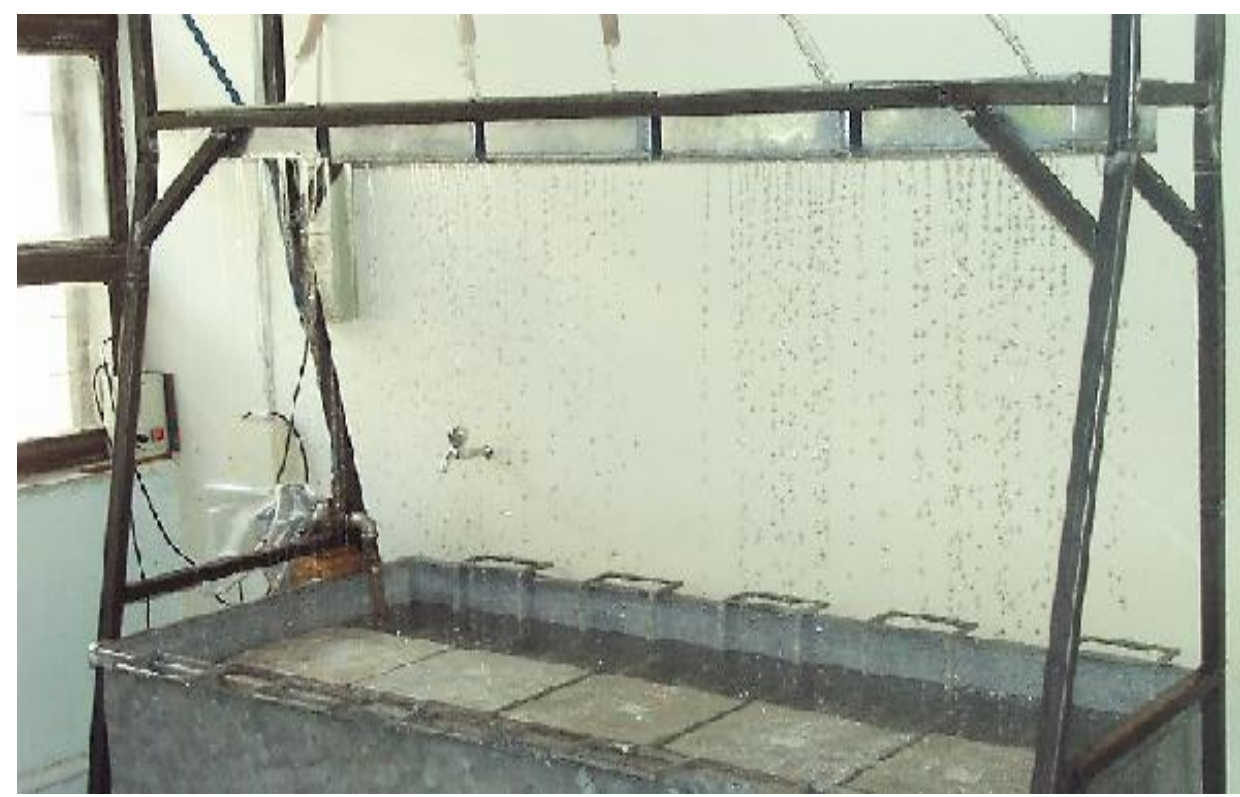

Şekil 1. Laboratuar ortamındaki aşınma deney düzeneği

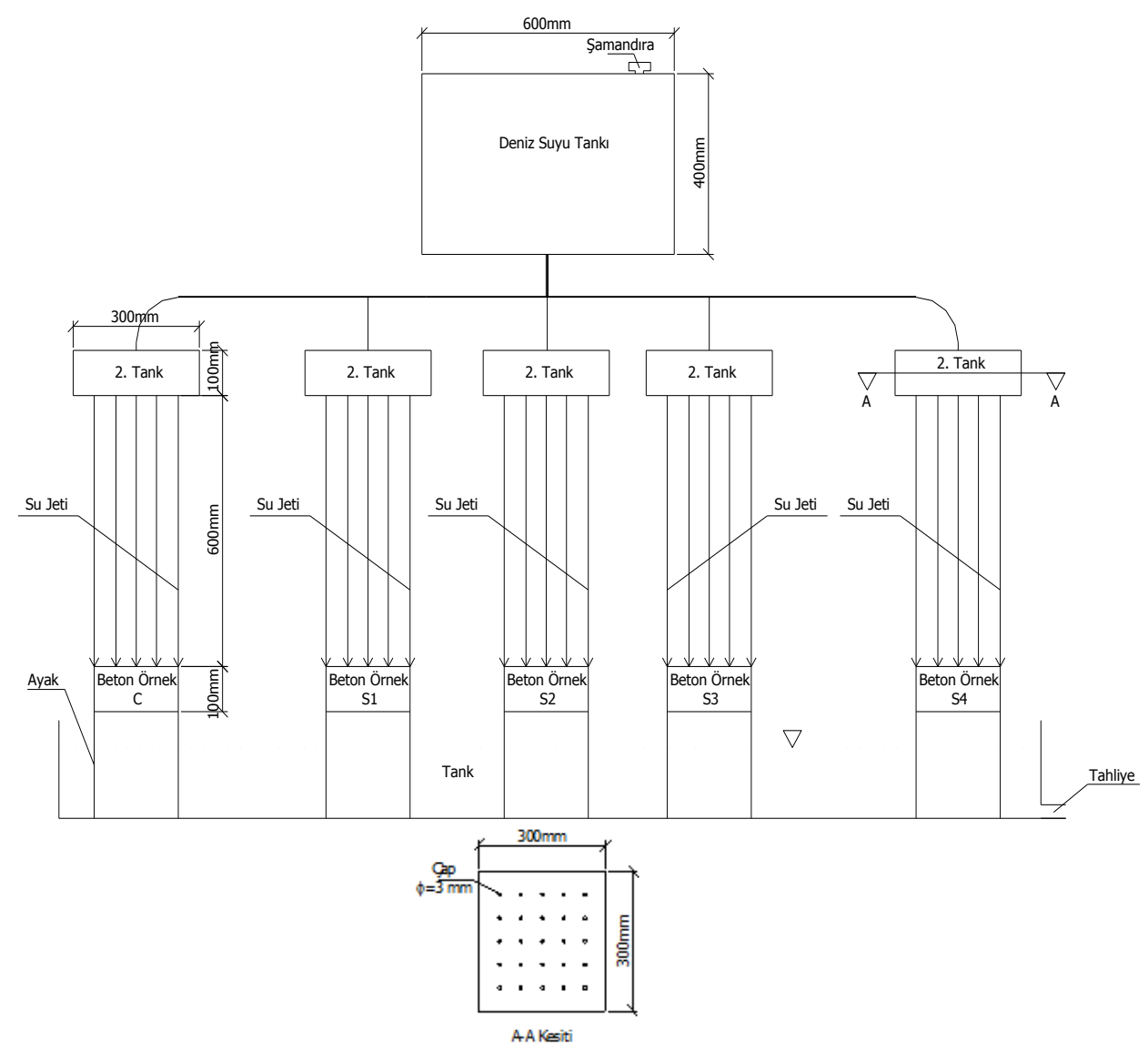

Şekil 2. Laboratuar ortamındaki aşınma deney düzeneğinin plan ve kesiti 


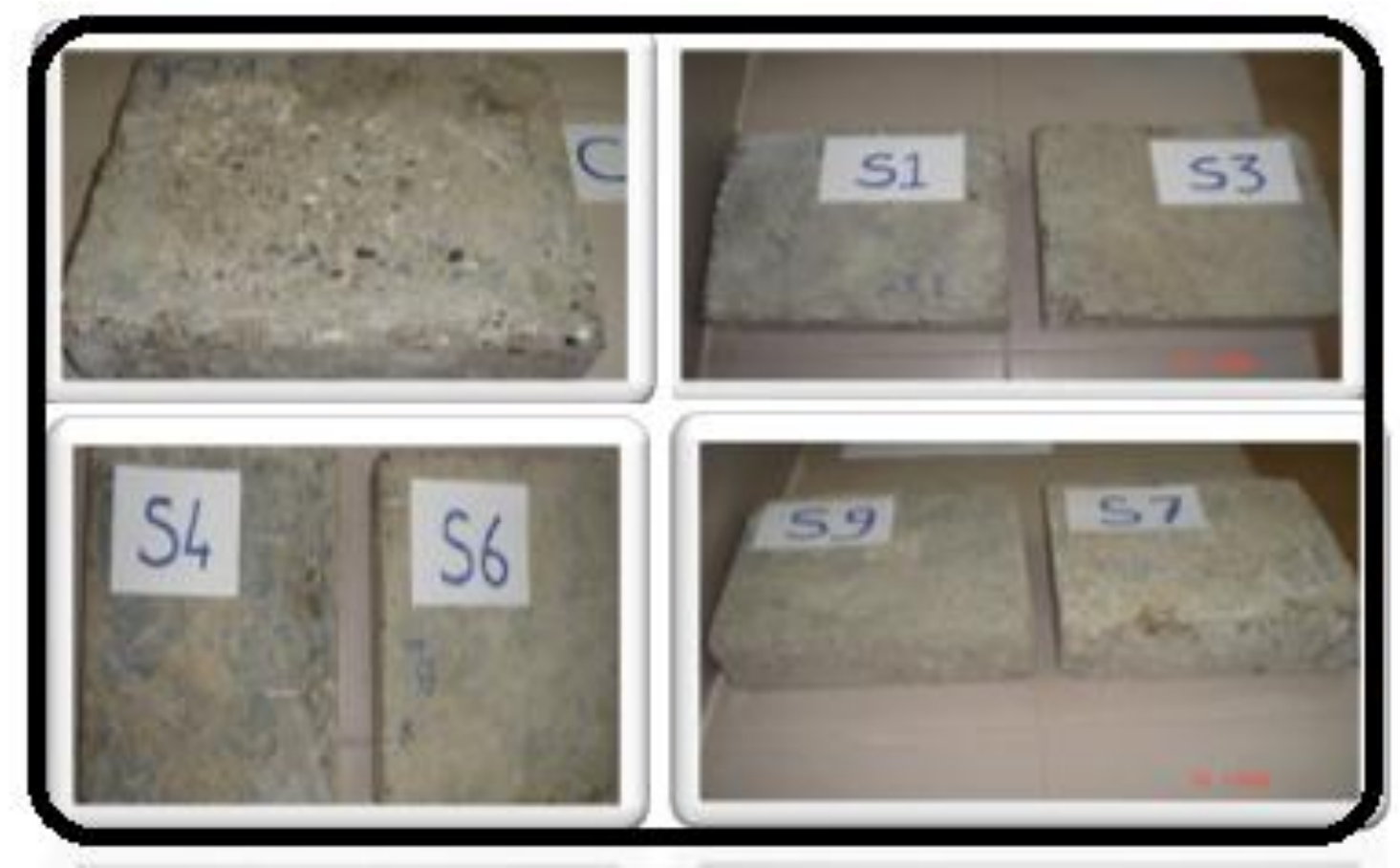

Şekil 3. Aşınmış Örnekler

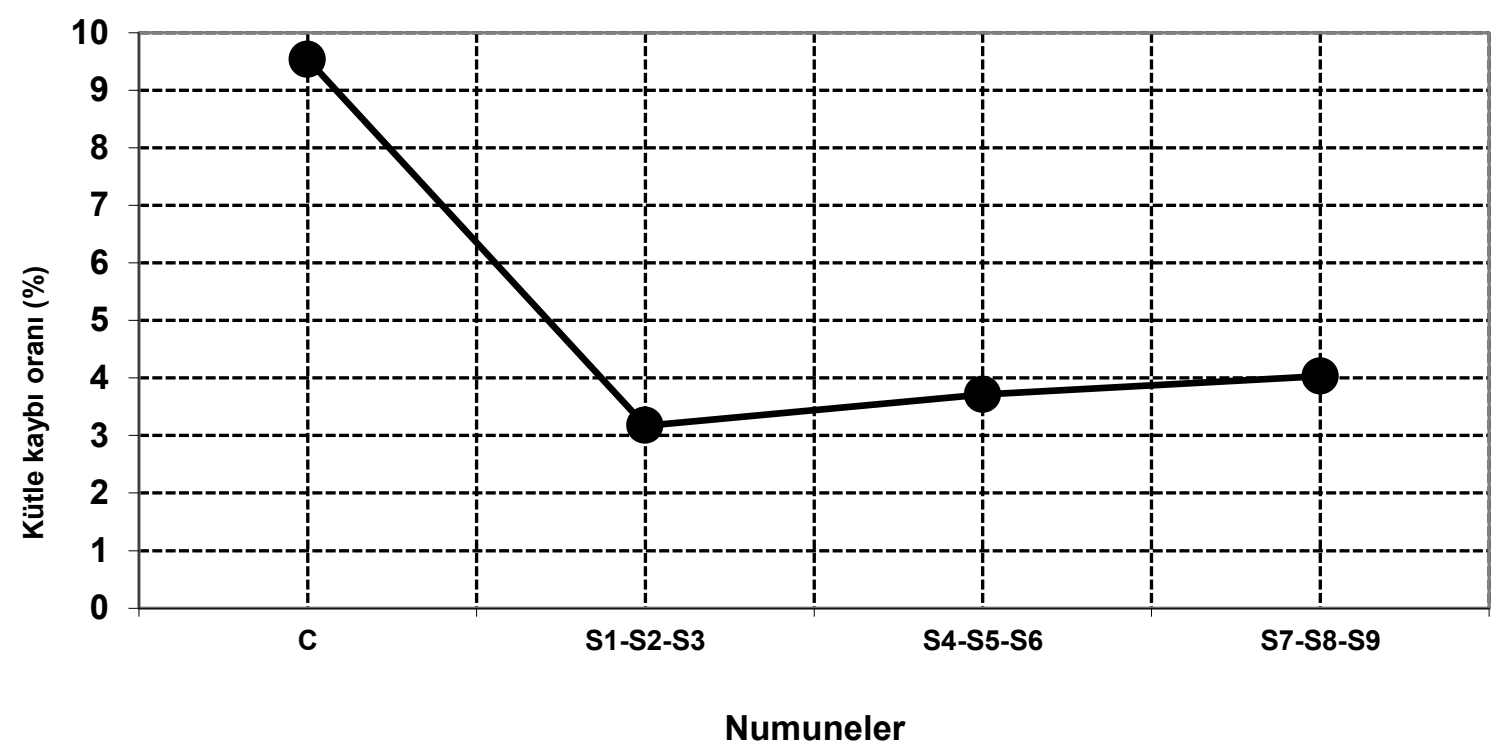

Şekil 4. Deniz ortamında bekletilen örneklerin 36 ay sonra kütle kaybı 
3.2. Denizde Yapılan Deneyde İnce Agrega Türünün Örneklerin Aşınma Dayanımına Etkisi

Şekil 5, Şekil 6 ve Şekil 7'de deniz ortamında bekletilen örneklerin sirasıyla 12 aylık, 24 aylık ve 36 aylık aşınmaları grafik olarak verilmişstir.
Her 3 grafikte de en fazla aşınma kontrol örneklerinde görülürken, kontrol örneğinden sonra, 12 ve 24 aylık periyotlarda en fazla kütle kaybı S9 örneğinde, 36 aylık periyotta ise en fazla kütle kaybı S7 örneğinde görülmektedir. \% 40 pomza ve $\% 40$ cüruf kullanılarak üretilen örnekler deniz ortamında aşınmaya karşı en fazla dayanımı gösteren örneklerdir.

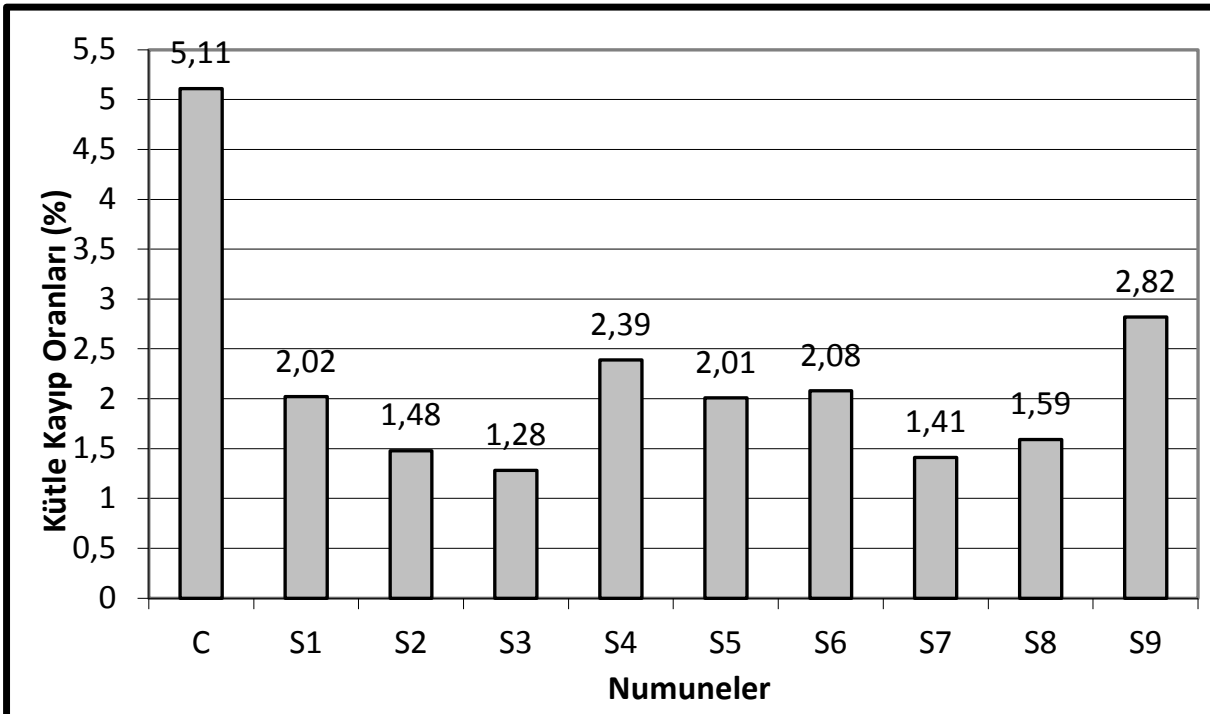

Şekil 5. Deniz ortamındaki örneklerin 12 ay sonra kütle kayıp oranları

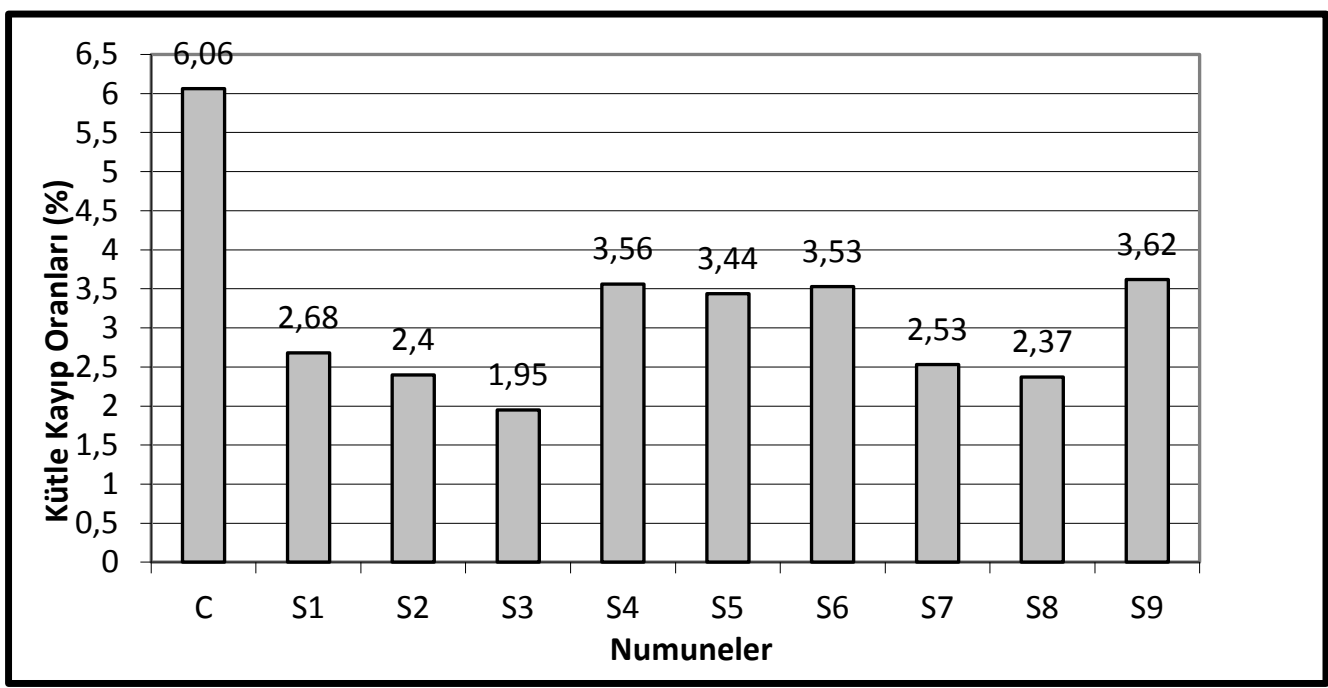

Şekil 6. Deniz ortamındaki örneklerin 24 ay sonra kütle kayıp oranları 


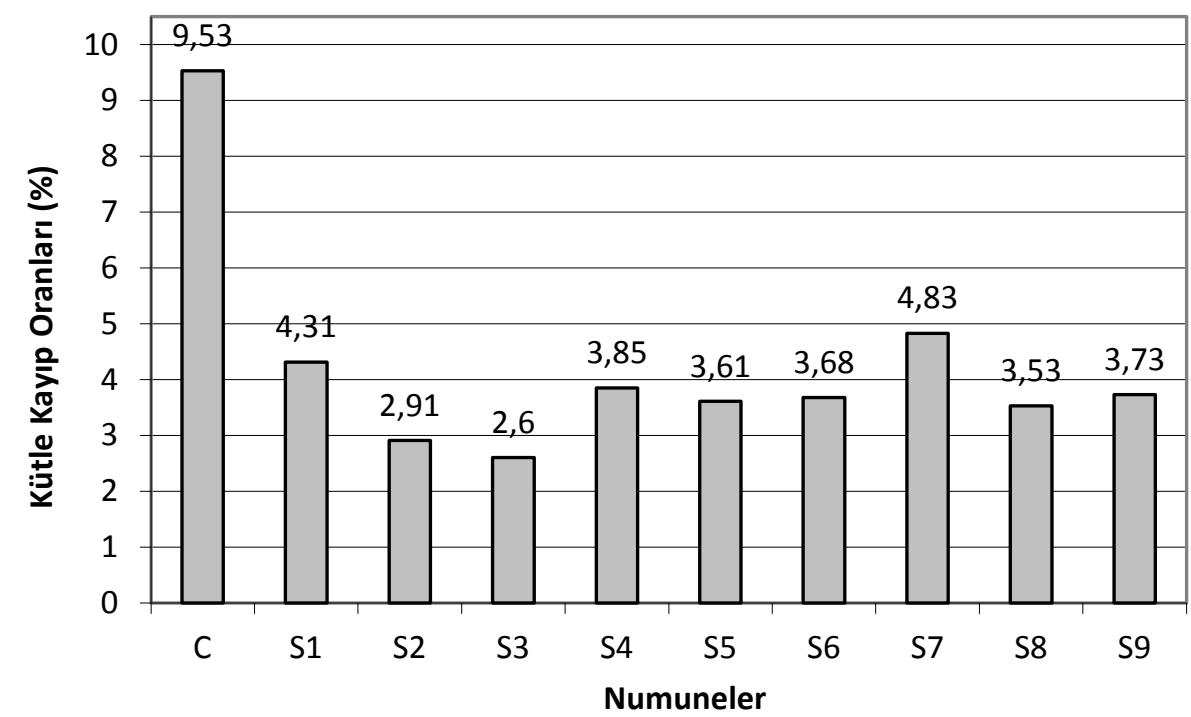

Şekil 7. Deniz ortamındaki örneklerin 36 ay sonra kütle kayıp oranları

\subsection{Laboratuar Ortamında Bekletilen Beton Örneklerin Aşınma Değerleri}

Deniz ortamında kullanılan örneklerin aynısı, laboratuar ortamında kurulan sistem içinde bekletilerek aşınmaya karşı dayanımları gözlenmiştir. 36 aylık gözlem sonuçları Şekil 8'de verilmektedir.
Kontrol örneği, deniz ortamında olduğu gibi laboratuar ortamında da en fazla kütle kaybı gösteren örnek olmuştur. 36 aylık periyotta, en fazla kütle kaybını \% 8,3 oranla kontrol örneği ve sonrasında S7, S8 ve S9 örnekleri göstermiștir. En az kütle kayb1 \% 2,02 oran ile S1, S2 ve S3 örneklerinde görülmektedir.

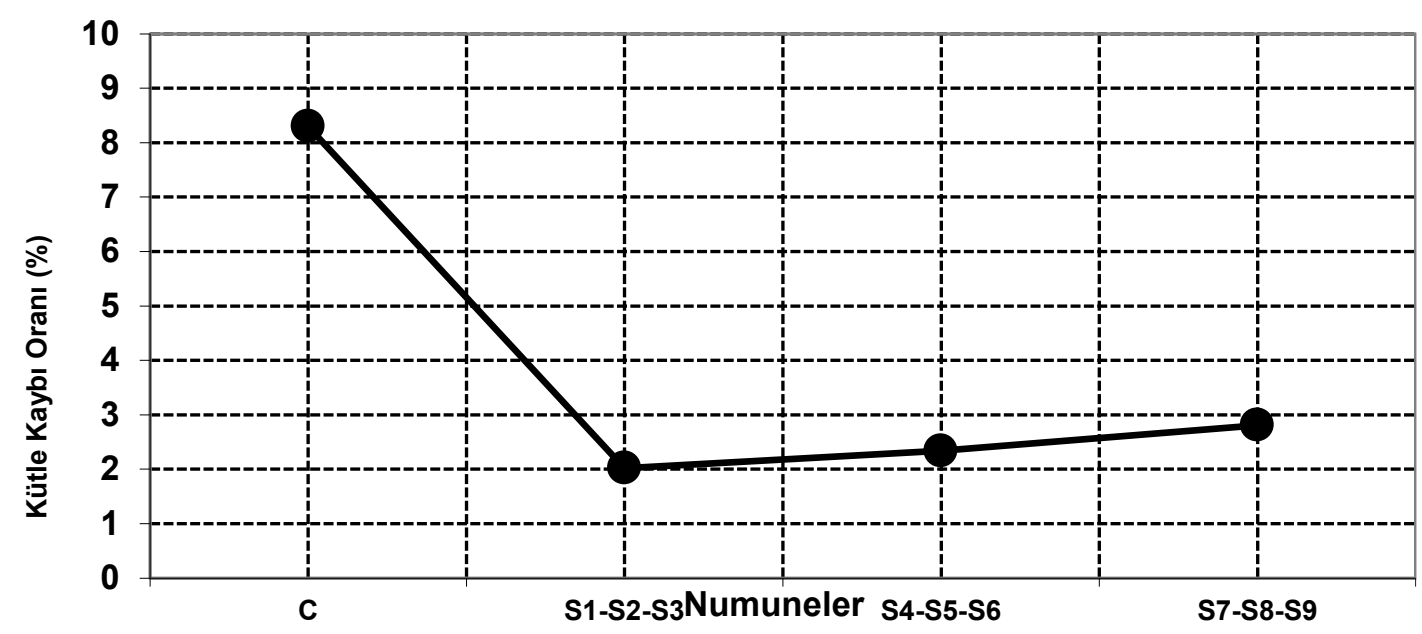

Şekil 8. Laboratuarda ortamındaki örneklerin 36 ay sonra kütle kaybı 


\subsection{Laboratuar Deniz Suyuyla Yapılan Deneyde İnce Agrega Türü Örneklerinin Aşınma Dayanımına Etkisi}

Şekil 9'da laboratuar ortamında bekletilen örneklerin 36 ay sonundaki kütle kayıplarının grafiği verilmektedir. Deniz ortamında ve laboratuar ortamındaki örneklerde en fazla kütle kaybı kontrol örneğinde gözlemlenmiștir. Kontrol örneğinden sonra, en fazla kütle kaybını \% 2,88 oranla S7 örneği, en az kütle kaybı \% 1,63 oran ile S3 örneğinde görülmektedir. Deniz ortamında bekletilen örneklerden elde edilen sonuçlar, laboratuar ortamındaki örneklerden elde sonuçlarla paralellik göstermektedir. S1, S2, S3 için deniz ortamında ortalama aşınma değeri \% $\quad 3,17$ laboratuar ortamında \% 2,32, S4, S5, S6 için deniz ortamında $\% 3,71$, laboratuar ortamında $\% 2,32$ ve S7, S8, S9 için ise bu ortalama değer deniz ortamında \% 4,03 laboratuar ortamında ise \% 2,57 olarak bulunmuştur. Kontrol örneği için bulunan değer ise deniz ortamında \% 9,53 laboratuar ortamında ise \% 8,3'dür. Bu sonuçlar, kontrol örneğinin; GBP ve YFC eşit miktarda katılarak üretilen örneklerin yaklaşık 3 katı daha fazla aşındığını göstermiştir.
Diğer örneklerin de aşınma değerleri aynı şekilde kontrol örneğinden azdır. Bu sonuçlar aşınmaya maruz olan elemanların betonunda pomza ve yüksek firın cürufu kullanılmasının aşınma etkisini azaltabileceğini göstermiştir.

\section{SONUÇLAR VE ÖNERİLER}

Çalışmada aşağıdaki sonuçlar elde edilmiştir.

1. Denizde ve laboratuvarda yapilan testler sonucunda Granüle Bazaltik Pomza ve Yüksek Fırın Cürufu eşit miktarda katılarak üretilen örneklerin aşınma değerleri kontrol örneğinden çok daha azdır. Bu yüzden kavitasyonun önemli olduğu yerlerde kullanılacak beton üretiminde, ince agrega yerine katkı olarak pomza ve yüksek firın cürufu kullanılmasının kimyasal aşınma etkisini azaltabileceğini göstermiștir.

2. Mekanik aşınma sonuçlarına göre kontrol örneği en az aşınma gösterdiğinden özellikle mekanik aşınmanın ön plana çıktığı yerlerde (su kanalları, beton yollar, hava alanı vb.) kullanılacak betonlarda kireçtaşı esaslı kırma taş kullanılması uygun olacaktır.

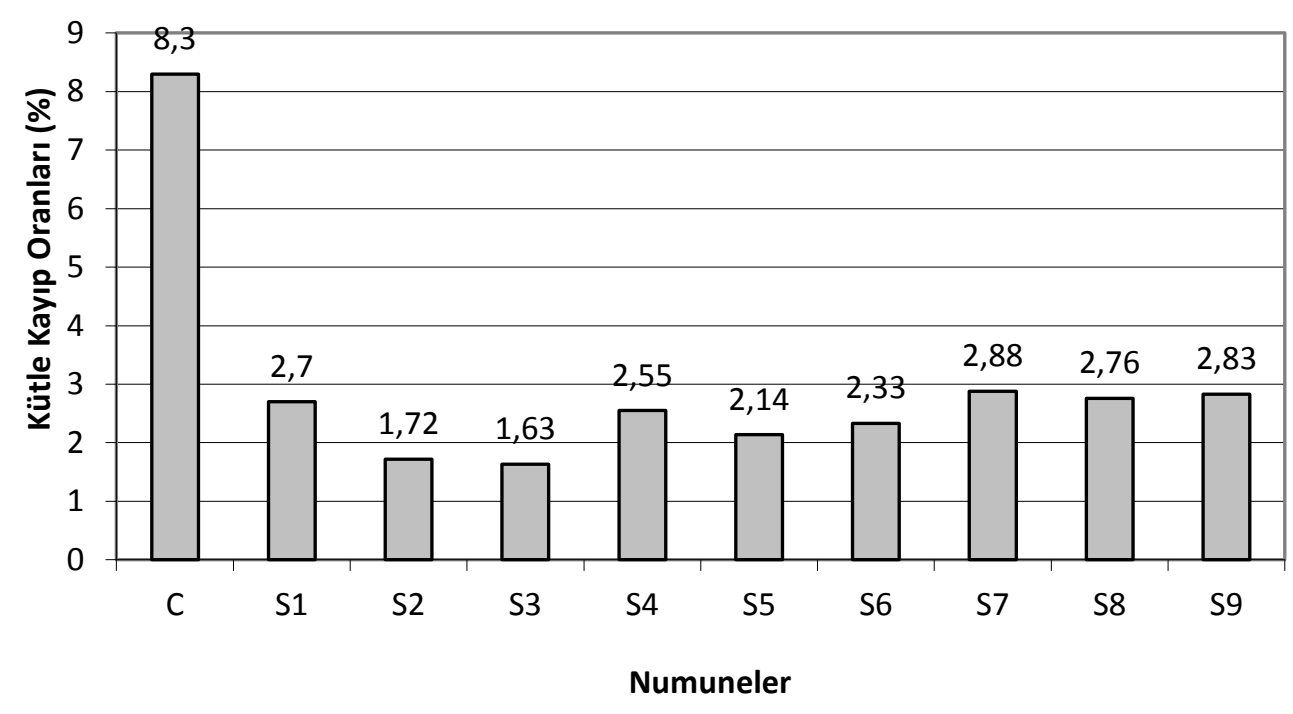

Şekil 9. Laboratuarda ortamındaki örneklerin 36 ay sonra kütle kayıp oranları 
3. Betonların aşınma direnci; Yüksek Fırın Cürufu ve Granüle Bazaltik Pomza katkıları arasında direkt ilişki vardır.

4. Elde edilen sonuçlara göre, deniz içerisinde inşa edilecek, sülfat ve tuz etkisinin bulunduğu yapıların beton üretiminde Granüle Bazaltik Pomza ve Yüksek Fırın Cürufu ince agrega kullanılabileceğini göstermektedir. Bu sayede sözü edilen kimyasal ve fiziksel yıkımların önüne geçilebilir veya etki düzeyi azaltılabilir. Fakat bu katkılar belirli bir oranda tutulmalıdır.

\section{KAYNAKLAR}

1. CEB (Comite Euro - International du Beton), 1992. Durable Concrete Structures, Lausanne: Thomas Telford Ltd.

2. ACI 201.2R - 92 , 1992. Guide to Durable Concrete Manual of Concrete Practice, American ConcreteInstitute, Detroit.

3. ACI 318, 2000. Building Code, American Concrete Institute, Detroit.

4. Postacıŏ̆lu, B,. 1986. Bağlayıı1 Maddeler Beton, 1 175. Matbaa Teknisyenleri Basımevi, İstanbul.

5. Sadegzadeh M, Page C. L,and Kettle C.J,. 1987. Surface Micro Structure and Abrasion Resistance of Concrete, Cement Concrete Research, 17) 581-590.

6. Horszczaruk E,. 2005. Abrasionresistance of High Strength Concrete in Hydraulic Structures, Wear, $25962-69$.

7. Ramezanianpour A. and Haghollahi A,. 2004. Investigation and Modelling of Abrasion in Industrial Concrete Floors, Amirkabir J. Science Technology, 115 55-61.

8. Atiş C.D, Karahan O, Arı K, Çelik Ö and Bilim C,. 2009. Relation Between Strength Properties (flexuralandcompressive) and Abrasion Resistance of Fiber (steelandpolypropylene) Reinforced Fly Ash Concrete, J. Mater. Civil Enginering, 21402 408.

9. Oymaeland S, Yeğinobalı A,. 1996. Bitümlü Şist Külü Katkısının Betonda Aşınma Dayanımına Etkisi, Proceedings of the Fourth National Concrete Conference, 359-367.
10. Binici H,. 2007. Effect of Crushed Ceramic and Basaltic Pumice as Fine Aggregates on Concrete Mortars Properties, Construction and Building Materials, 211191-1197.

11. Binici H, Aksogan O, Kaplan H, Gorur E.B, Bodur M.N, 2009. Hydro-Abrasive Erosion of Concrete Incorporating Groundblast-Furnace Slag and Ground Basaltic Pumice, Construction and Building Materials, 23 804811.

12. Binici H, Aksogan O, Kaplan H, Gorur E.B, Bodur M.N,. 2008. Performance of Ground Blast Furnace Slag (GBS) and Ground Basaltic Pumice (GBP) Concrete Against Sea Water Attack. Construction and Building Materials, 22 1515-1526.

13. Yüksel İ, Bilir T and Özkan Ö,. 2007. Durability of Concretein Corporating NonGround Blast Furnace Slag and Bottom Ash as Fine Aggregate, Building and Environment, 422651-2659.

14. Özışık, G., 1998. Beton İstanbul Üniversitesi Mühendislik Fakültesi, İnşaat Mühendisliği Bölümü, İstanbul.

15. Topçu İ.B., 2006. Agregaların Mekanik Özellikleri. TMMOB İnşaat Mühendisleri Odas1, 226. 
